\title{
THE DISAPPEARING ARABS BEFORE ISLAM: BEYOND ORIENTALISM. PREFACE TO THE INTERNATIONAL EDITION
}

This is not a conventional history book. It is rather a study of the sociology of historical writing about a period that, although quite distant in time (330 B.C. to A.D. 670), still influences political discourse about the Arab world, and especially the relationship between the West and the Middle East.

This book focuses on the riddle of the disappearance of the Arabs from history before Islam, their sudden appearance behind the banners of the Prophet, and the powerful and traumatic effect this emergence into world history has had on the relationship between the Arabs and the West.

Although the mainstream Western historical narrative does not see the Arabs before Islam as a political or cultural force, or even as members of a defined cultural unit, Arab historians and more traditional Western sources do permit a rather different picture once misguiding or obscuring labels have been removed. In this study, Arabia and the Arabs appear as a region and people that enjoyed considerable linguistic, cultural, religious, and political cohesion centuries before Islam. The appearance of the Prophet was, from this perspective, the culmination of a historical process that had already been long underway - perhaps delayed by Roman interference in the East and the establishment of the Roman diocese of Oriens, but also reinforced by Hellenistic-Roman culture and religious thought. In this scenario, the 
rise of Islam is in no way surprising or in need of explanation as a retrospective forgery, as the revisionist school would have it.

Uncovering this historical process involves answering two questions: what was the history of the pre-Islamic Arabs under their Hellenistic and Roman rulers, and why has that history disappeared?

There is evidence that the Arabs, under different names and labels (Semites, Saraceni, Barbaroi, Indignae...), were in fact a kind of consolidated union with a shared cultural consciousness, although of course not in the form of an Arab nation in the modern sense. The situation was perhaps similar to that of the Germanic tribes, who would not have described themselves as "Germanic" even though they were aware of their shared characteristics, which were also clear to the Romans who fought and colonized them. Although it may seem surprising in the context of contemporary attitudes to the Middle East, this Arab Kulturnation was closely politically and culturally integrated into the Hellenistic-Roman world. Moreover - contrary to the current prevailing view - the Greeks themselves were well aware that a considerable portion of their own culture had originated in the Middle East and Africa. The Greek and Arab regions were by no means antagonistic poles, but rather mutually influencing spheres - as would be expected of cultural systems that had been interacting for many centuries. ${ }^{1}$ This allows us to move past the idea of "Orient oder Rom," the belief that Rome and the East were elements of different historical systems. Instead, we can show that such a belief is the result of current political and cultural circumstances being projected back onto the past.

Why did this history disappear? Although the period was certainly no "dark age" with silent sources and scarce archaeological remains, there seems to be a desire to deconstruct the Arab world into smaller elements - local or regional cultures,

1 This academic discussion, or rather battle, between those who emphasize Greek culture's Aryan or Semitic roots, respectively, has been treated extensively by Martin Bernal in Black Athena: The Afroasiatic Roots of Classical Civilization (London: Random House 1991), 337ff. 
civilizations, and languages - that make it difficult to identify a wider Arab sphere, an area of shared Arab language and culture. The Arab victory over Rome and the loss of the Christian heartland in the Middle East, sealed by the unsuccessful crusades some centuries later, were a traumatic experience for the West. Christianity had to be reimagined and redefined as a Western religion. Suddenly, the joint historical experience of East and West, their common roots and cultural exchanges, became a burden. As Edward Said showed, Arabs needed to be seen as different, as the "Other." 2

This led to two reactions. First, Arabs and their long history of interaction with the Hellenistic-Roman world had to be suppressed. Second, the Arabs' military success against Rome and Christianity in the seventh century had to be explained away as an opportunistic seizing of the "critical moment," or even as the result of dishonest strategies used against an otherwise more sophisticated and culturally and religiously superior power. Ar$\mathrm{ab}$ integration and participation in the Greco-Roman world had no place in this narrative. When the West began to return to the Orient in the $18^{\text {th }}$ century, the imperialist and colonial idea was legitimized by a belief in the superiority of Western culture and religion. Ethnically Arab Roman Emperors, senators and scientists were a clear contradiction and even an impediment in this context, which also saw the rise of an intellectual anti-Semitism that further reinforced the underlying processes and attitudes.

Of course, history could not be fully suppressed, and memories remained. To strengthen the idea of Western superiority against a once and perhaps still dangerous adversary, negative images of the pre-Islamic Arabs were absorbed into the narrative of the "Clash of Cultures" introduced by the Orientalist Bernhard Lewis in the 1990s. As this book shows, these negative images are the result of a highly selective approach to historical sources that, in reality, portray a much more nuanced situation. The Arabs appear in these sources as Roman allies and citizens,

\footnotetext{
${ }^{2}$ Edward Said, Orientalism (New York: Pantheon Books, 1978), 31ff.
} 
bound to Rome in a difficult and complex relationship in which Christianity played in important role.

Edwards Said's groundbreaking work on Orientalism and its arguments can now be updated: the portrayal of the Arab as the "Other" was a necessary step in the process of muting a thousand years of close interaction between Arab and Greco-Roman culture. The image of Arabs as barbarians draws selectively on historical sources that have been stripped of their context, concealing their writers' individual circumstances and attitudes towards the Arabs.

At the least, this book should make available a fascinating stretch of history that seems to contradict current views of the Western-Arab relationship. What are these powerful sources we may wonder - that are capable of shaping historical narratives in such a specific, antagonistic way, despite the fact that traditional Western sources were able to admit other explanations? If the writing of history depends - more even than we perhaps wish or imagine - on interpretation, interpretation itself is always molded by the attitudes, values, and motives of the commentator. Moreover, as this book shows, interpretations, once set in motion, are then reinforced by scientific methods that deconstruct the field into smaller pieces, digging deeper into specific subject areas while neglecting the overall historical system and its longue durée. ${ }^{3}$

Such conclusions may make us feel uneasy. If such a significant piece of history can be so severely contested and interpreted in so many different ways; if the Arabs themselves seem to be unable to reclaim their history, being for the most part seen as

\footnotetext{
${ }^{3}$ This is something that Said addressed in his responses to his critics, including Albert Hourani, who saw Orientalists in a more neutral role: "I do insist on the prevalence in the [Orientalist] discourse itself of a structure of attitudes that cannot simply be waved away or discounted. (...) I suppose that one can imagine at the limit that a specialist in Ottoman or Fatimid archives is an Orientalist in Hourani's sense, but we are still required to ask where, how and with what supporting institutions and agencies such studies take place today." Said, Orientalism, 342 .
} 
outsiders to the Western scientific community, what hope is there for a relationship between the Arab world and the West that is based on mutual appreciation, recognition, and trust? It is our hope that the translation of the original German version of this book may help broaden interest and promote discussion about this historical period.

This book would not have been possible without the help and support of Professor Peter Gran, who kept a close eye on the German edition and the debate it provoked. Many thanks also go to my German editors at Duncker \& Humblot, Berlin, for their support of this edition. 
